in which he gives the sum of his own practical experience, with a digest of what had been done by others. Though much of these two little pocket volumes has been superseded by the progress of science, they remain as an admirable summary of the geology of their time, while many of their sound practical directions may be usefully read and remembered in all time coming. The closing sentences of the preface may be quoted here for their personal reference. "Thrown from my earliest days on the highways of the world, as most of my kin have been, having spent my life among seven capitals of Europe, and having near relatives in a dozen cities of the north-west and centre of this continent, my travelling disposition may be easily understood, and my irresistible tendency to a vagabond life. I was left an orphan at eleven years, and became entirely master of my own movements at twenty. This want of a fixed residence, this facility of moving about and making myself at home everywhere, adopting the customs and language of each country, must naturally have taught me to travel, and may to some extent excuse my pretension to say more on these matters than others. I have traversed a good part of Europe, and have been able to examine in detail all the formations of this continent. In spite of trying adventures, it is no mere invalid who now speaks and bids adieu to an active life, but one who, having seen much during a period of twenty years, believes that he may usefully recapitulate his observations for the benefit of his fellows, before again starting on the wandering life to which fate seems to have condemned him. The West flees from me, the East summons me; my grave shall be where heaven may please." During one of his sojourns in Paris he and a few others founded the present distinguished Geological Society of France. In a letter which I had from him at the time of the jubilee of the Society last year, he writes: "The Geological Society of France was created in my library room, April I, I830; present were Brongniart (Alex.), Cordier, Férussac, Blainville, Constant Prevost, Jobert-all dead. [This is not quite correctly remembered; for the meeting took place on March 17, I830, in the rooms of the Philomathic Society of Paris, Boué himself in the chair.] They wish I should preside at this solemn meeting, but at eighty-six years of age, with my infirmities, it was impossible." He was one of the early presidents of the Society, and through life continued to take a paternal interest in its welfare.

Some forty years ago or more, after many wanderings in Austria and the adjacent countries, Boue obtained a piece of land at Vöslau, on the last spurs of the Eastern Alps, looking over the great plain which stretches eastwards to the Carpathian mountains. There were at the time few or no houses about the place, and the three or four acres acquired by Boué were a free gift from the proprietor to encourage building there. Now it is a fashionable watering-place for the Viennese, with numerous villas and hotels gathered round a copious hot spring, the water from which is caught in a swimming basin. I visited the veteran there in 1869, and found him established for the summer among his vineyards and his orchard well stocked with quinces, almonds, peaches, and apples. He had no children, but had adopted as a daughter a relative of his wife. It was charming to see the enthusiasm with which he threw himself into everything that he did. In spite of severe suffering and numerous operations of lithotomy he still retained, for an old man of seventy-five, an extraordinary vigour and vivacity. $\mathrm{He}$ made wine enough not only to supply his own needs, but to sell to the dealers, and looked after every detail of the process as if wine-making had all along been the only occupation of his life. He took me with him on some interesting excursions in the neighbourhood, and warm though the weather was, he walked at a pace to which even young geologists are not accustomed in this country.
It was delightful, too, to listen to his reminiscences of old times. He had known most of the geologists of note of the century, and had corresponded with all of them. He had amusing little personal recollections to give, mostly in English, which he would now and then, when the words failed him, exchange for German. He remembered down to the minutest details his life at Edinburgh and his rambles in Scotland. Now and then in a pause of our talk, as his memory drifted back again into the old student days, his face would lighten up with a sudden gleam of satisfaction as he would question me as to some quarry or brook-section he had visited more than half a century before, and which stood out as distinctly as if it were again in front of him. At his town house in Vienna, whither he used to return for the winter, he showed me his tabulated geological indices, in which he said that every geological work or memoir published in his time in every language was catalogued. It is much to be desired that these indices, which were carefully written out by himself, should be promptly published. They are particularly full, I believe, in the department of physical geology. $\mathrm{Up}$ to the last he retained his interest in the progress of the science, and communicated thoughtful papers on the work of others when no longer able to make original researches himself. The many long letters he wrote to me were always full of gossip as to the doings of his friends in Vienna, and shrewd remarks on passing events, scientific or otherwise. They were always in English, as I have said, but often with such strange idioms and spelling as occasionally made their meaning not very clear. I am tempted to give a quotation from one which $\mathrm{I}$ re= ceived from him in November, 1870, during the time of the Franco-German war:- "I was retain to late in the country this year by bad weather. My vintage did protract itself so late in October that we are hardly established comfortably now in town. Besides, the dreadful war preoccupations did take me all time from thinking at scientific matter, and now perhaps that distress will approach till nearer our abode. When you will know that I have very good and near parents in both armies and you perceive the possibility of parents killing themselves without recognising themselves, nor having the opportunity to do so, you will understand that I have often headach when I ride the newspapers or hear from the quite useless slaughters which have been prevented only by those men at the head of the human Society. I have parents in Paris, other exiled in Spain in England in Switzerland. The country houses of some by Paris are German hospitals or barracks. ... As descending from Frenchmen I fill myself quite happy to be a German and to have remain such my whole life on."

With the regret that accompanies the severance of a tie that links us with so many interesting associations of the past there mingles in no common measure the feeling of personal bereavement. Retired for so many years in his Austrian retreat, Boué kept up the freshness of his youthful sympathy with progress and the kindliness of his hearty exuberant nature. May the dust lie light on his honoured head! To have even seen his round, goodnatured face and sparkling eye was something to remember with satisfaction; but to have been privileged with his friendship was an honour the recollection of which will be more than ever precious to those from whom it has now been for ever withdrawn.

\section{ARCH. GEIKIE}

\section{NOTES}

THE International Exhibition of Smoke-abating Appliances at South Kensington was opened yesterday with great éclat. The opening meeting was held in the Albert Hall, the Lord Mayor in the chair, supported by the Marquess and Marchioness of Lorne, Doctors Siemens and Frankland, Captain Galton, 
Sir H. Thompson, Lord Aberdare, and many men of science and others interested in the movement. The following awards will be made :-A prize of roo guineas, given by $\mathrm{Dr}$. Siemens; two prizes, together of about 100 guineas, given by larlies interested in the National Health and Kyrle Societies, for the best domestic fire-grate; the Society of Arts medals ; a prize of $50 l$., given by the Manchester Association for the Prevention of Noxious Vapours, and certificates to be awarded by the Council.

THE Annual Meeting of the Royal Society was held yesterday. The usual business was transacted. Part of the President's interesting address will be found in another column.

Mr. H. N. Moseley, F.R.S., has been elected to the Linacre Chair of Physiology in the University of Oxford, vacant by the death of Prof. Rolleston. We heartily congratulate Prof. Moseley and the University of Oxford, whose appointment must be regarded with genuine satisfaction.

BARON NORDENSKjöld was in town for a few days last week, leaving again on Sunday, much to the disappointment of many who wished to make up for the poor reception he met with when be called here on his way home round Europe and Asia. It will be remembered that he reached London on a Good Friday, when no one expected him, and when we were in the throes of an exciting parliamentary election. His present visit was therefore looked forward to as affording an opportunity of showing worthily England's appreciation of his great work. Unfortunately, however, he was compelled to leave before anything conld be done. Baron Nordenskjöld's narrative of his great voyage will be published in a very few days, and will, we believe, besides describing the incidents and discoveries of his own voyage, contain a narrative of research on the northern shores of Europe and Asia from the earliest times down to the present day. Its scientific value is likely to be very great.

IN consequence of an appeal from Mr. Leigh Smith's relations and friends, the Council of the Geographical Society on Monday last resolved to ask the First Lord of the Admiralty to receive a deputation from their body, accompanied by experienced Arctic navigators, who will urge upon him the necessity for taking immediate steps for the relief of the Eira. It is considered by Mr. Smith's friends that a well-equipped and commanded steamer alone can meet the requirements of the case, as it is not impossible that the Eira may have met with some serious disaster, and that it would certainly be necessary to visit without delay Eira Harbour and other points on the south coast of Franz-Josef Land. Perhaps a more modest request that two or three gunboats should at once be ordered to cruise up and down the ice-limit during the winter, and keep a bright look in all directions, might receive more attention, and would in the end probably prove as effective, and certainly less dangerous than the other plan. The Eira left Peterhead in the midule of June, and appears to have been only once spoken, viz. by the Norw.egian vessel Proven. She first met the Eira on June 30 , steering for the Matyushin Shar, and eight days later met her again steering a northerly course. It may fairly be assumed, therefore, that in the mean time Mr. Leigh Smith had made an ineftectual attempt to pass through the strait.

IN his report for the present year General W. B. Hazen, Chief Signal Officer of the United States, makes some useful remarks on International Polar research. From the progress made by the Signal Corps in the study of meteorology in late years, it has become clear that, owing to the very mobile nature of the atmosphere, the changes taking place in one portion of the globe-especially the Arctic zone-quickly affect very distant regions. The study of the weather cannot be properly carried on without a daily map of the whole of the northern hemisphere, and the great blank space of the Arctic region has long been a source of regret. General Hazen was, therefore, glad to cooperate in the work of the International Committee on Polar Re. search in their project for forming Arctic and Antaretic Stations. Their general object will be to accomplish by observations made in concert at numerous points such additions to our knowledge as cannot be acquired by isolated or desultory travelling parties. No special attempt will, he says, be made at geographical exploration, nor will there be any endeavour to reach the North Pole. The U.S. Signal Service undertook to organise two of these expeditions this year, one of which, as we know, was safely established under Lieut. Greely, in August last, at Discovery Harbour, Lady Franklin Bay, and we are glad to be able to announce that the other, under Lieut. Ray, was left in safety at Point Barrow on September 17 by the Golden Fleece, in which vessel it had been conveyed from San Francisco. The position of the former station, we may add, is in N. lat. $8 \mathrm{I}^{\circ} 4 \mathrm{O}^{\prime}$, W. long. $64^{\circ} 30^{\prime}$.

ON Monday last an unusually interesting paper was read before the Geographical Society by Mr. E. C. Hore of Ujiji, on his experiences in East Central Africa, and more particularly on Lake Tanganyika. His knowledge of Lake Tanganyika is unrivalled, as he has examined it carefully along its whole coast-line of some 900 miles, and he has crossed it in various parts. His description of the River Lofu, at the southern end, was very effective, and the same remark applies to the scenery of various parts of the lake-shore. Mr. Hore says that there are ten tribes living along its coast region, and he referred to their industries, including peculiar modes of fishing, and the species of co-operation among them which raised them far above the level of the natives on the sea-coast. He mentioned a number of the products of the country, among which are various kinds of timber used for making canoes, spear-heads, \&c. Two species of crocodile are found in the lake, and $\mathrm{Mr}$. Hore created some amusement by saying that Stanley's water-hyænas, on investigation, turned out to be otters. Owing to the singular formation of the Iake, its depth is a matter of some interest; but all Mr. Hore can say is that he could obtain no buttom with about $\mathrm{r} 70$ fathoms of line. Among the other matters dealt with were visits to the Lukuga outlet of the lake, the current of which has lately got much slacker, and the Malagarasi, one of the largest rivers emptying into the lake. At Mr. Hore's first visit the latter was 500 feet broad, with a swift current and rapids five and a half miles from its mouth. On subsequent visits the channel was found comparatively empty, a result largely brought about by the lowering of the lake level.

MR. E. C. HORE has presented to the Geographical Society the map of Lake Tanganyika which he constructed from careful surveys and observations made during his various explora. tions, the results of which he described in his paper above referred to.

M. Plateau describes as "un petit amusement" the fol. lowing experiment:-A flower like a lily, with six petals each about an inch long, was constructed in outline in thin iron wire; the wire being first slightly peroxidised by dipping for an instant into nitric acid. This wire frame was then dipped into a glycericsoap-solution, which, when it was withdrawn, left soap-films over the petals. The stalk was then set upright in a support, and it was covered by a bell-glass to protect it from air-currents. In a few moments the most beautiful colours made their appearance. If the solution is in good condition the films will last for hours, giving a perpetual play of colour over the flower.

THE stories which we have from time to time heard respecting an alleged discovery of relics and journals of the long-lost explorer, Dr, Ludwig Leichhardt, and upon which discredit has lately been thrown, would appear to have some foundation after all, for by the last Australian mail news has been received that 
the New South Wales Government have agreed to the somewhat exorbitant demands of the bushman, Mr. J. R. Skuthorpe, and will give him $6000 l$. for the relics, \&c., provided their genuineness be established by certain tests. Mr. Skuthorpe has now no excuse for keeping his alleged "find" buried in the far interior, and it cannot be long before the matter will be settled one way or the other. Mr. Skuthorpe is stated to have given an outline of the contents of the journals, among which are accounts by Classen of Dr. Leichhardt's death and his own life among the natives.

Prof. HAeckel is at present in Ceylon, where he is to stay for three months for a scientific exploration of the island.

THE German Government is considering the participation of German men of science in the plan of International Polar Research. The Reichstag has been asked to grant the necessary funds, which are fixed at 300,000 marks $\left(1_{5}, 000 l\right.$.). Besides this sum 180,000 marks $(9000 l$.) are asked for the Transit of Venus Expedition in 1882 , and 75,000 marks (3750l.) for expeditions to Central Africa.

THE forthcoming lecture arrangements at the Royal Institution will include the usual Christmas course of six lectures, to be given this year by Prof. R. S. Ball, the Astronomer-Royal of Ireland, on the Sun, Moon, and Planets (with illustrations by the electric light, \&c.). Eleven lectures by the new Fullerian Professor of Physiology ; four lectures by Prof. H. N. Moseley on Corals; four lectures by Dr. P. L. Sclater on the Geographical Distribution of Animals ; three lecture; by Prof. Tyndall; four lectures by Prof. Pauer on Louis van Beethoven (with illustrations on the pianoforte); four lectures by Mr. W. Watkin Lloyd on the Iliad and Odyssey. The Friday evening meetings will begin on January 20 at 8 p.m. Dr. W. Huggins will give a discourse on Comets. Succeeding discourses will probably be given by Mr. R. S. Poole, Professors Odling, Frankland, J. G. M'Kendrick, and W. E. Ayrton, Capt. Abney, Mr. A. Tylor, Mr. J. W. Swan, Mr. W. Spottiswoode, and other gentlemen. Mr. H. H. Statham's four lectures on Ornament, delivered at the Royal Institution, are to appear in the Portfolio for January and following months.

Preparations are being made in Edinburgh for the celebration of the centenary of Sir David Brewster's birth next month.

MR. EDIson has entered the field of competitors in the con. struction of storage batteries for electric currents. His particular method of storing currents has however not yet been made public.

The Daily Nerus Naples correspondent writes that a small party of travellers is proceeding to India, one of whom is Paolo Mantegazza, the organiser of the expedition, the object of which is, on his part, to make anthropological studies of the Indian races, and to collect skulls and bones for the Museum at Florence. One of his companions, Signor Fabricotti, a naturalist, will collect animals and plants, and the other, Signor Michela, an artist, will reproduce or copy the antique Indian ornamentation of the monuments, china and bronzes, that adorn Indian temples and houses. Signor Mantegazza is particularly interested in the races of the Himalaya, and, after a general survey of India, it is to this region that the attention of himself and of his companions will be especially devoted.

Herr J. N. Arosenius gives in the last number of the Zeitschrift für die wisstnschaftliche Geographie (vol. ii. fascicule 5), an account of the ethnographical frontier between Finns and Swedes in Northern Sweden. This frontier does not coincide either with the old one, which ran along the range of hills between the Torneo and Kemi rivers, or with the present one which runs along the Torneo. It begins on the shore of the
Gulf of Bothnia, between the post stations Sangits and Säivits, and runs straight north to the Kengis iron-works. But some three or four hundred miles south-west of this frontier there are in Sweden numerous small patches inhabited by Finns, which patches make a broken chain going from the Wermland to the Medelpad province. The flat land and the valleys altogether are inhabited by Swedes, but nearly everywhere in the most remote parts of the forest are to be found one or several Finnish houses, built in the old Finnish fashion. Isolated in the wilds, Finnish people in Sweden gradually forget their former language, and mostly speak Swedish, especially after having reached a certain age. In the province of Dalarne the Finnish language is quite forgotten by the Finns, and their origin can be discovered only by their customs, dwellings, and by very few remains of their former language; thus M. Arosenius has seen a woman who knew only a single Finnish sentence, one of the most frequently used, however, "Light me the pipe." As to the remains of Finnish population in the province of Smaland, the question still remains open; but it is proved that there are remains of two different peoples, one of which must have been of Lapp origin, whilst the other, which knew the use of bronze implements and agriculture, must have been, M. Arosenius thinks, Finnish.

Don Justo Zaragoza contributes to the Boletin of the Geographical Society of Madrid a series of interesting papers on ancient canal schemes between the Atlantic and the Pacific in Central America. There were three places which the Spanish of the sixteenth century thought of for these schemes: the isthmus of Tehuantepec in New Spain, now Mexico; the river of San Juan, of the Lake of Nicaragua, in the republic of the same name; and the Chagre River, and other parts of the Isthmus of Panama. The investigation of Tehuantepec was abandoned at that time, to be renewed in our century; those of Nicaragua were actively pursued in the seventeenth century, and were nearly being executed about the middle of the eighteenth century, during the reign of Charles III., and the scheme of a canal through the Isthmus of Panama, also abandoned, has now been renewed by $M$. Lesseps. In the paper published in the October number of the Boletin D. Zaragoza gives interesting information on the little-known scheme of a canal via the Lake of Nicaragua, which scheme appeared in the year 1548 , with a map of the land prepared by Arias Gonzalo. In 1606 Captain Ochoa de Leguizamo explored, on the same account, the Puertos de Caballos and Fonseca Bay; and during the years I 780 to 1783 a map of the projected canal, still existing, was prepared, and a survey was made between the Pacific and the Lake of Nicaragua, which last proved to be 133 Castilian feet above the sea-level, the height of the water-shed being 604 feet. This scheme met with great opposition, the chief reason for which was found in the statement of Juan Bautista Antonelli, an engineer sent by Philip II., who declared the scheme quite impracticable; and D. Zaragoza publishes an interesting memoir, by J. Antonio de Escartin, to prove the possibility of the canal. The paper will be continued.

Prof. A. H. Church gives a course of lectures on Chemistry at the Royal Academy of Arts on December 2, 7, 9, 12, 14, and I6; of course the lectures will have special reference to the bearing of Chemistry on Art.

Admiral Mouchez is continuing with vigour the completion of his astronomical museum. Eight oil paintings have been placed in the foreign astronomers' room, representing respec tively Copernicus, Tycho Brahé, Galileo, Kepler, Huyghens, Newton, Bradley, and J. Herschel. A large number of engravings and photographs, representing either celebrated astronomers, large instruments, or foreign observatories, have been collected in the same room. 
A VERY hopeful Report has been published by the Winchester College Natural History Society. This is its Fifth Report, though the Society has been in existence ten years. It has not been thought necessary to publish any account of the doings of the Society for five years, though we are assured that it has been none the less doing good work. This is what is wanted, and the present report bears evidence that the Winchester Society is in a healthy and fairly vigorous condition. The sectional reports are good, and the Society has formed some very fair collections.

The Berlin Philosophical Society, founded in 1843 by the disciples of Hegel, but now numbering amongst its members men of the most various philosophical creeds, has applied the surplus of funds recently collected for a monument in memory of Hegel to the foundation of a Hegel Institution, the object of which is the furtherance of philosophical research. The Society has just issued the following prize theme : "A critical and historical account of the dialectical method of Hegel." The treatises may be written either in German, French or English, and must be sent in before December $3 \mathbf{I}, \mathbf{1} 883$. The prize is 450 marks (22l.).

A NEW natural history serial will soon be published by Enke of Stuttgart. Its editor is Dr. Georg Krebs of Frankfort on the Maine, and its title, Humboldt, Monatsschrift fïr die gesammten Naturwissenschaften.

THE " Encyklopædie der Naturwissenschaften," published by Trewendt of Breslau, is now well advanced. Part 25 contains the seventh instalment of the Dictionary of Zoology, Anthropology, and Ethnology, and only brings it down to Distoma. Parts 26 and 27 contain the eleventh and twelfth (the concluding) instalment of the Handbook of Mathematics.

DR. NAGORSKY, having measured the capacities of lungs of 630 boys and 314 "girls in the schools of the district of St. Petersburg, now publishes the results of his investigation in a Russian medical paper, the Surgeon. He has found that the capacity of lungs, in relation to the weight of the body, is 65 cubic centimetres for each kilogramme of weight in boys, and 57 cubic centimetres for girls. The law of Quetelet being that with children below fifteen years of age, the weight of the body is proportionate to the square of the height, Dr. Nagorsky has found that it is proportional to $2 \cdot 15$ of the same; whilst the capacity of lungs is proportional to $24^{\text {th }}$ of the height for boys, and to the square of the height for girls. Dr. Nagorsky's rescarches will soon be published as a separate work. As to the relation between the weight of man and the capacity of lungs, it is tolerably permanent, and its variations are mostly due to differences in the amount of fat in the bodies of different men.

IN our article o the Geological Congress (NATURE, November Io) in the table of terms, in the first column of p. 35 , the word Cycle should be Ere (era).

THE additions to the Zoological Society's Gardens during the past week include a Vervet Monkey (Cercopithecus lalandii) from South Africa, presented by Mr. R. M. Edger; a Blackbird (Turdus merula), two Song Thrushes (Turdus musicus), a Starling (Sturnus vulgaris), two Skylarks (Alauda arvensis), a Greenfinch (Ligurnis chloris), two Chaffinches (Fringilla calebs), two Common Quails (Coturnix communis), British, presented by Mr. Edward Lawrence; a Black-winged Peafowl (Pavo nigripennis) from Cochin China, presented by Mr. J. Marshall; a Common Kestrel (Tinnunculus alaudarius), British, presented by Mr. A. Lidbury; a Grecian Ibex (Capra agagrus) from South-East Europe, four Orange-cheeked Waxbills (Estrelda melpoda), two Common Waxbills (Estrelda cinerea) from West Africa, two Maja Finches (Munia maja) from Malacca, a Blackbeaded Finch (Munia malacca), an Indian Silver-bill (Munia malabarica) from India, a Song Thrush (Turdus musicus),
British), a Blue-crowned Parrakeet (Tanygnathus luzonensis) from the Philippines, a White-eared Conure (Conurus leucotis) from Brazil, deposited; a Bar-tailed Godwit (Limosa lapponica), two Razorbills (Alca torda), two Common Lapwings (Vanellus cristatus), two Golden Plovers (Charalrius pluvialis), two Knots (Tringa canutus), a Red-throated Diver (Colymbus seplen. trionalis), British, purchased; a Spotted Ichneumon (Herpestes auropunctatus) from Nepal, a Geoffroy's Dove (Peristera geoffroiz), two Brazilian Teal (Querquedula brasiliensis) from South America, two Mandarin Ducks (Aix galericulata) from China, received in exchange.

\section{OUR ASTRONOMICAL COLUMN}

The Saturnian System.-In a memoir publi.hed in t. xxvii. $2^{\text {me }}$ partie, of Mémoires de la Société de Physique et d'Histoire Naturelle de Genève, entitled "Recherches sur Saturne, ses Anneaux et ses Satellites," M. Wilhelm Meyer, assistant-astronomer at the Observatory of Geneva, presents results of his observations made with the ro-inch refractor, the gift of Prof. Plantamour to the establishment, during the opposition of 1880 . They consist of measures of the rings and equatorial and polar diameters and observations of the satellites Enceladus, Tethys, Dione, Rhea, and Titan, with elements deduced from them. M. Meyer was not certain that he had observed Mimas in 1880 , but in a note he mentions that on the night of September 4, 188I, which was " une des plus belles, quant à la diaphanité de l'atmosphère," he obtained an undoubted observation of it; at $13 \mathrm{~b}$. $13 \mathrm{~m}$. $27 \mathrm{~s}$. Greenwich mean time it was distant $3 \mathrm{I}^{\prime \prime} \cdot \mathbf{I}$ from the centre of Saturn, exactly in the plane of the ring on the preceding side, or, as he expresses it, $x=-3^{\mathrm{I}^{\prime \prime} \cdot 1}, y=0$.

For the outer diameter of ring A he finds $40^{\prime \prime} \cdot 47$ for the mean distance of Saturn, which, like other measures with the filarmicrometer (employed for all the measures at Geneva) is in excess of the results given by the double-image micrometer; Kaiser found the outer diameter with the latter $39^{\prime \prime} 477$. Considering the difficulties attending measures of this class with the filar-micrometer, preference, no doubt, is to be given to the double-image principle, though without much practice there may be a tendency to clip the measures made with the instrument. If it were preferred to take something like a general mean of the reliable measures to this time, the outer diameter of the ring would be found to differ little from $39^{\prime \prime} \cdot 75$.

M. Meyer has referred all his times to the meridian of Greenwich, because, as he says, it is that adopted by Mr. Marth in the calculation of his elaborate ephemerides of the satellites, to which he acknowledges his obligations.

We subjoin the elements of the four satellites interior to Titan which were measured at Geneva:-

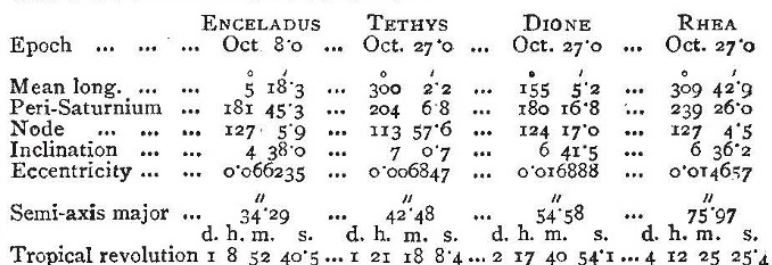

The node and inclination are referred to the plane of the terrestrial equator.

The separate values of the mass of Saturn which M. Meyer deduces from his observations are discordant.

The Lunar Eclipse on December 5.-The eclipse of the moon next Monday evening, though very nearly total, will not be actually so, the magnitude being 0.973 . The first contact with the shadow occurs at $3 \mathrm{~b} .28 \mathrm{~m}$., but the moon does not rise at Greenwich till $3 \mathrm{~h}$. 50m. The middle of the eclipse occurs at $5 \mathrm{~h} .8 \mathrm{~m}$., and the last contact with shadow at $6 \mathrm{~h}, 49 \mathrm{~m}$. The shadow enters upon the moon's surface at about $60^{\circ}$ from the $\mathrm{N}$. point of the limb towards the east. The fifth magnitude star $\downarrow$ Tauri is occulted at Greenwich at $6 \mathrm{~b}, 23 \mathrm{~m}$, , before the shadow is off the disk.

On October 13,1856 , there was a lunar eclipse of similar character, magnitude o*994.

VARIABLE STARS. - R Leporis. According to Dr. Julius Schmidt's observations during the interval $1865-1875$, the mean 